
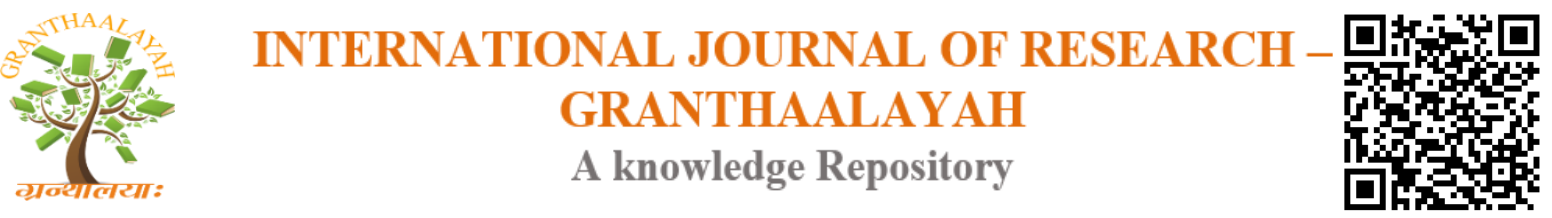

Science

\title{
REPRODUCTIVE BIOLOGY OF THE MULLET LIZA FALCIPINNIS (VALENCIENNES, 1836) IN TWO AFRICAN COMPLEXS LAGOONS (EBRIÉ AND GRAND-LAHOU) (CÔTE D'IVOIRE)
}

\author{
Ebram Luc Gervais DJADJI *1, Soumaila SYLLA ${ }^{1}$, Tizié Thierry ZAN-BI ${ }^{1}$, Boua Célestin \\ ATSE ${ }^{1}$ \\ ${ }^{* 1}$ Centre de Recherches Océanologiques, B.P.V 18 Abidjan, Côte d'Ivoire Fax (225) 213511 \\ 55
}

\begin{abstract}
The reproduction of Liza falcipinnis were investigated in both lagoons (Ebrié and Grand-Lahou) from January 2006 to december 2007. 2162 specimens were examined (914 and 1248 respectively in Ebrié and Grand-Lahou lagoons). Fork length was taken to the nearest $1 \mathrm{~mm}$, and total body weight (TW) and eviscerated body weight (EW) to the nearest $0.1 \mathrm{~g}$. The gonads and the liver were then established removed, weighted to the nearest $0.001 \mathrm{~g}$. The reproduced period of Liza falcipinnis was established by analysing the temporal evolution of the frequency of the maturity stages and the monthly variations in the gonadosomatic index (GSI), the hepatosomatic index (HIS) and the condition factor (K). Sex ratio was established taking into account the sex determinations. The size at which $50 \%$ of the specimens became mature (FL50) was estimated. The sex ratio (1:1.24) and (1:1.40) observed respectively in Ebrié and Grand-Lahou lagoons were in favour of females. The first sexual maturity size was $21.0 \mathrm{~cm}$ (FL) for males and $27.9 \mathrm{~cm}$ (FL) for females in Ebrié lagoon and $24.7 \mathrm{~cm}$ (FL) for males and $27.9 \mathrm{~cm}$ (FL) for females in GrandLahou lagoon. Liza falcipinnis spawns in lagoon and the spawning period ranged from December to April.
\end{abstract}

Keywords: Sex Ratio; Fecundity; Spawning Period.

Cite This Article: Ebram Luc Gervais DJADJI, Soumaïla SYLLA, Tizié Thierry ZAN-BI, and Boua Célestin ATSE. (2018). "REPRODUCTIVE BIOLOGY OF THE MULLET LIZA FALCIPINNIS (VALENCIENNES, 1836) IN TWO AFRICAN COMPLEXS LAGOONS (EBRIÉ AND GRAND-LAHOU) (CÔTE D'IVOIRE)." International Journal of Research - Granthaalayah, 6(5), 114-127. https://doi.org/10.29121/granthaalayah.v6.i5.2018.1433.

\section{Introduction}

Studies of fish reproduction are biologically and ecologically (Albaret and Legendre, 1985). Mugilidae are cultured in many countries due to their high quality flesh (Sahar, 2004). They are of great economic importance in tropical inland waters of West Africa and they play significant roles in the ecology of African freshwater (Robert and Jessa, 2003). The abundance of mullets in 
estuarine and coastal areas of all tropical and sub-tropical regions of the world may be related to their food and feeding habits, as they occupy a relatively low position in the food web (Wright, 1988). In Ivory Coast, Mugil cephalus and Liza falcipinnis as being those which, among local mullets, show the highest potential for fish culture (Albaret and Legendre, 1985).

The present paper wants to fill a devoid and carrie at Liza falcipinnis reproduction in the two complexs lagoons (Ebrié and Grand-Lahou). The objective of this study was to evaluate biological features, such as sex-ratio, size at sexual maturity, reproduction periodicity and the fecundity.

\section{Material and Methods}

\subsection{Study Area}

In Côte d'Ivoire, lagoons (Aby, Grand-Lahou, Ebrié) were essentially presents along the maritime front. These areas go together $1200 \mathrm{~km}^{2}$. They benefit to equatorial climate of transition with two high seasons, rainy (April to July) and dry (December to March) and two little seasons, the rainy marked by the continental flood (October to November) and the dry (August to September). The Ebrié and Grand-Lahou complexs lagoons stretch out East to West respectively on $130 \mathrm{~km}$ and 50 $\mathrm{km}$ and have been connected permanently to the sea (Figure 1) (Durand and Guiral, 1994). Their areas were $566 \mathrm{~km}^{2}$ and $190 \mathrm{~km}^{2}$ respectively in Ebrié and Grand-Lahou complexs lagoons. These systems were little deep $4.8 \mathrm{~m}$ in Ebrié and $3 \mathrm{~m}$ in Grand-Lahou. Ebrié system was permanently connected to the sea from the canal of Vridi. The salinity gradient is very marked, ranging from 0 $\mathrm{g} / \mathrm{l}$ in rain season to $30 \mathrm{~g} / \mathrm{l}$ in dry season (Durand and Guiral, 1994). The average temperatures are high but present a low seasonal variation with a maximum at $31.2^{\circ} \mathrm{C}$ on the surface in April and a minimum at $27.4^{\circ} \mathrm{C}$ in August (Durand and Guiral, 1994). According to the salinity, Grand-Lahou lagoon can be divided into two distincts areas. The continental area where salinity ranging from 0 to $19 \%$ water. The oceanic area is salted with values ranging between $8 \%$ and $27 \%$. Water remains always brackish because they are influenced by the continental contributions (Konan et al., 2008). The average water temperature of this lagoon ranges between $25^{\circ} \mathrm{C}$ and $28^{\circ} \mathrm{C}$. The maximum values $30^{\circ} \mathrm{C}$ and $31^{\circ} \mathrm{C}$ were observed in March and in April during the great dry season and the minimal value $17^{\circ} \mathrm{C}$ in August during the little dry season because of the coastal upwelling. Fresh samples of Liza falcipinnis were collected from the Ebrié lagoon in three sites: N'djem and Layo with the salinity gradient varies from 0 to $30 \%$ and Gboyo from 0 to $3 \%$. On the other hand, Grand-Lahou lagoon two sites has been choiced, Braffédon with the salinity gradient varies from $25 \%$ to $0 \%$ and Mackey with a salinity from $10 \%$ to 3\%o (Figure 1). 

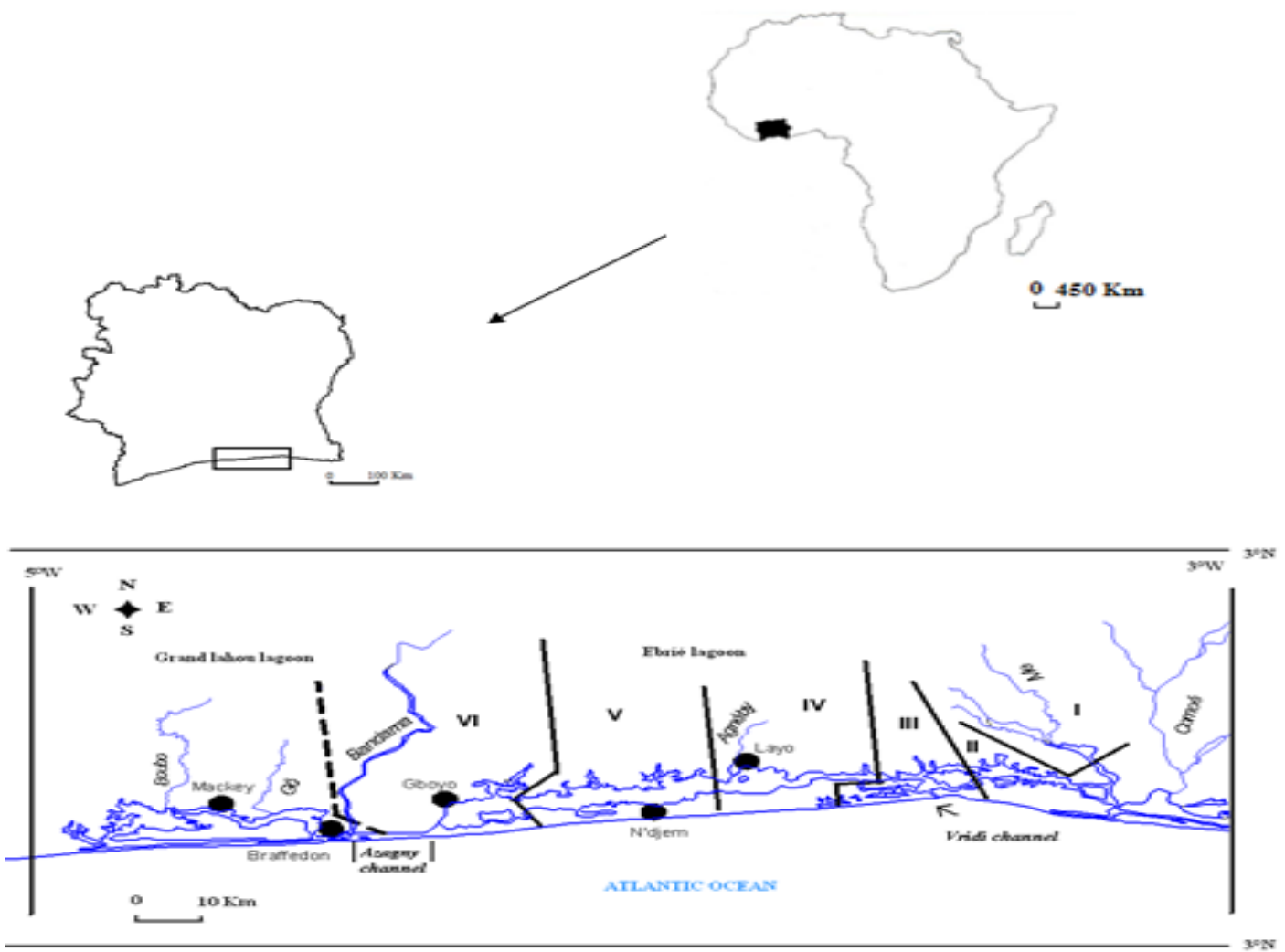

Figure 1: Map of Ebrié and Grand-Lahou lagoons (Côte D’Ivoire) and location of different Sampling sites $(\bullet)$

\subsection{Sampling}

Monthly samples of Liza falcipinnis were collected from the sites of Ebrié and Grand-Lahou lagoons (Campaign of monthly output of six consecutive days) during the period from January 2006 until December 2007. At each level lagoon, the experimental fishing have been effected at night and daylight. The fish were caught using three batteries of stitch fillet and differents links (10 to $50 \mathrm{~mm}$ ). The stitchs fillets were put at $5 \mathrm{pm}$ and relieved the next day at 7 am for the night fishing (Ntakimazi et al., 2000) and immediately, they were put at once again and relieved at $1 \mathrm{pm}$ for the day fishing. The fish were caught have been identified by identification key of Albaret Albaret (1992). All of the samples were kept on ice to the laboratory. Each fish was measured to the nearest $\mathrm{cm}$ for the fork length (FL), total body weight (TW) and eviscerated body weight (EW) were measured to the nearest $0.01 \mathrm{~g}$. The gonads and the liver were then removed, weighed to the nearest $0.001 \mathrm{~g}$. The sex was determined by the macroscopic investigation. The maturity stages were determined according to Ameur et al., (2003).

\subsection{Reproductive Parameters}

The size of the first sexual maturity was given for the males and the females while regarding as mature fish presenting of the gonads at the stage equal to or higher than 4 and 5 of sexual maturation(Ibanez Aguirre and Gallardo-Cabello, 2004). [10]. The proportion of mature individuals (P), by class of size of $1 \mathrm{~cm}$, was adjusted by the function of Ghorbel et al., (1996) according to the equation: 
With $\mathrm{P}=$ proportion of mature individuals; $\mathrm{FL}=$ Fork length

$\mathrm{A}$ and $\mathrm{b}=$ constants. Of this formula, we deduced the sizes with L50 (Ghorbel et al., 1996) by calculating the following report: FL50=.

Absolute fecundity was determined by counting of the oocytes of the ovaries in advanced vitellogenesis (only stage 5). The diameters of the oocytes were measured with the binocular magnifying glass provided with a micrometer (model Wild M3C). The diameter oocyte was estimated starting from measurements made on 30 ovocytes by females. The sex-ratio was calculated starting from individuals of known sex. The biological parameters which are: the gonado-somatic index (GSI); the hepato-somatic index (HSI) and the factor of condition (K) of the mature individuals (stage at least 4) were calculated monthly starting from the following formulas:

; et

With $\mathrm{GW}=$ gonad weight $(\mathrm{g}), \mathrm{EW}=$ eviscerated body weight $(\mathrm{g})$ and $\mathrm{LW}=$ liver weight $(\mathrm{g}) ; \mathrm{FL}=$ fork length $(\mathrm{cm})$.

The relationships absolute fecundity-fork length and absolute fecundity -total body weight were described respectively by the following equations: $F=$ a FLb and $F=a$ Wtb with $F=$ absolute fecundity; $\mathrm{FL}=$ fork length $(\mathrm{cm}) ; \mathrm{Wt}=$ total body weight $(\mathrm{g})$;

$\mathrm{a}=$ slope and $\mathrm{b}=$ ordered in the beginning.

\subsection{Statistical Analysis}

The analysis of variance (ANOVA) was used to determine the effects of the seasons (dry season and rainy season) and of the years (first and second year) on the GSI, the HSI and K according to the sex. The test of Tukey was used for the comparisons a posteriori. The differences are considered significant with $\mathrm{p}<0.05$. The percentages of the sexes were compared by means of the test of homogeneity $\left(\chi^{2}\right)$. The statistical analyzes were carried out with the software Statistica 7.1.

\section{Results}

\subsection{Sex Ratios and First Maturity Size}

A total of 1001 specimens (408 males, 506 females and 87 juveniles) in Ebrié lagoon and 1327 specimens of Liza falcipinnis (519 males, 729 females and 79 juveniles) in Grand Lahou lagoon were evaluated by opening the abdomens and examing the gonads. Of all the fish examined, 87 and 79 were immature what represented $8.69 \%$ and $5.95 \%$ of effectives respectively in Ebrié lagoon and Grand-Lahou lagoon. The sex ratios were 1:1.24 and 1:1.36 in favour of females in both lagoons. In the both lagoons, the sex ratio present a significant difference (Ebrié lagoon, $\chi 2=$ 10.50; $\mathrm{p}<0$. 05; Grand Lahou lagoon $\chi 2=35.34 ; \mathrm{p}<0$. 05). The spatio temporal distribution of sex ratios showed a predominance of females over the males however the lagoon (Table 1). Two periods of unequal distribution were observed in each lagoon. The Ebrié lagoon where from January to March and May to July then from October to November where the sex ratio is in favour of the females with strong proportions (1: 1.18 to 1: 7.67) on the other hand, in April, August to September, the sex-ratio is reversed in favour of the males (Table 1). As for the lagoon of Grandlahou, the phenomenon is the same one with a predominance of the females from February to 
April, June to July and October at December against January, March, August and September which are in favour of the males (Table 1).

Table 1: Fork length and sex ratio of Liza falcipinnis in Ebrié and Grand Lahou lagoons; $\mathrm{n}=$

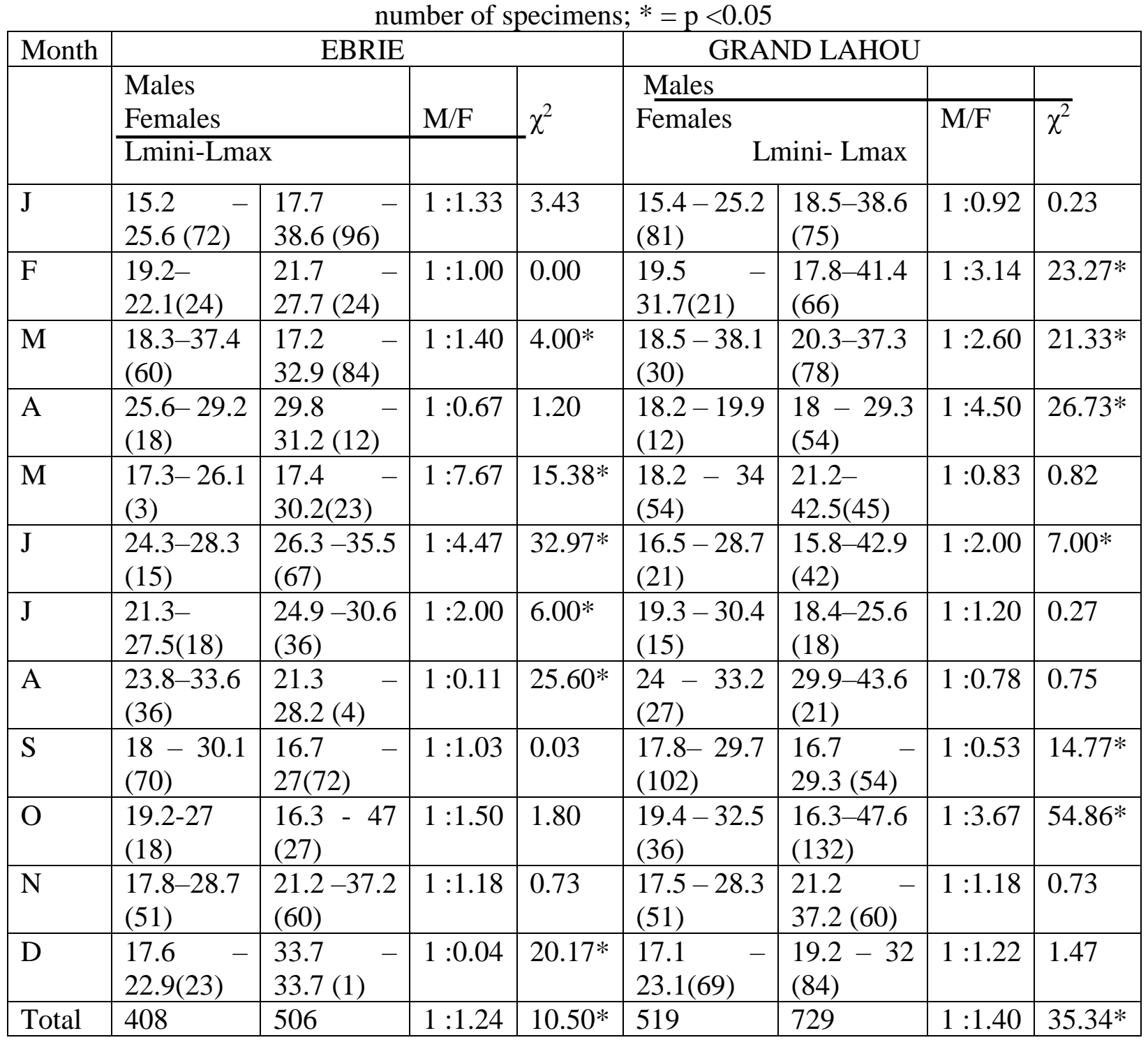

The first sexual maturity size was $21.0 \mathrm{~cm}$ (FL) for males and $27.9 \mathrm{~cm}$ (FL) for females in Ebrié lagoon and, $24.7 \mathrm{~cm}(\mathrm{FL})$ for males and $27.9 \mathrm{~cm}(\mathrm{FL})$ for females in Grand Lahou lagoon (Figure $2)$. But, any significant difference were observed between the both sex and the both lagoons $\left(\chi^{2}=\right.$ $0.97 ; p>0,05$ for males; $\chi 2=0.19 ; p>0,05$ for females). 

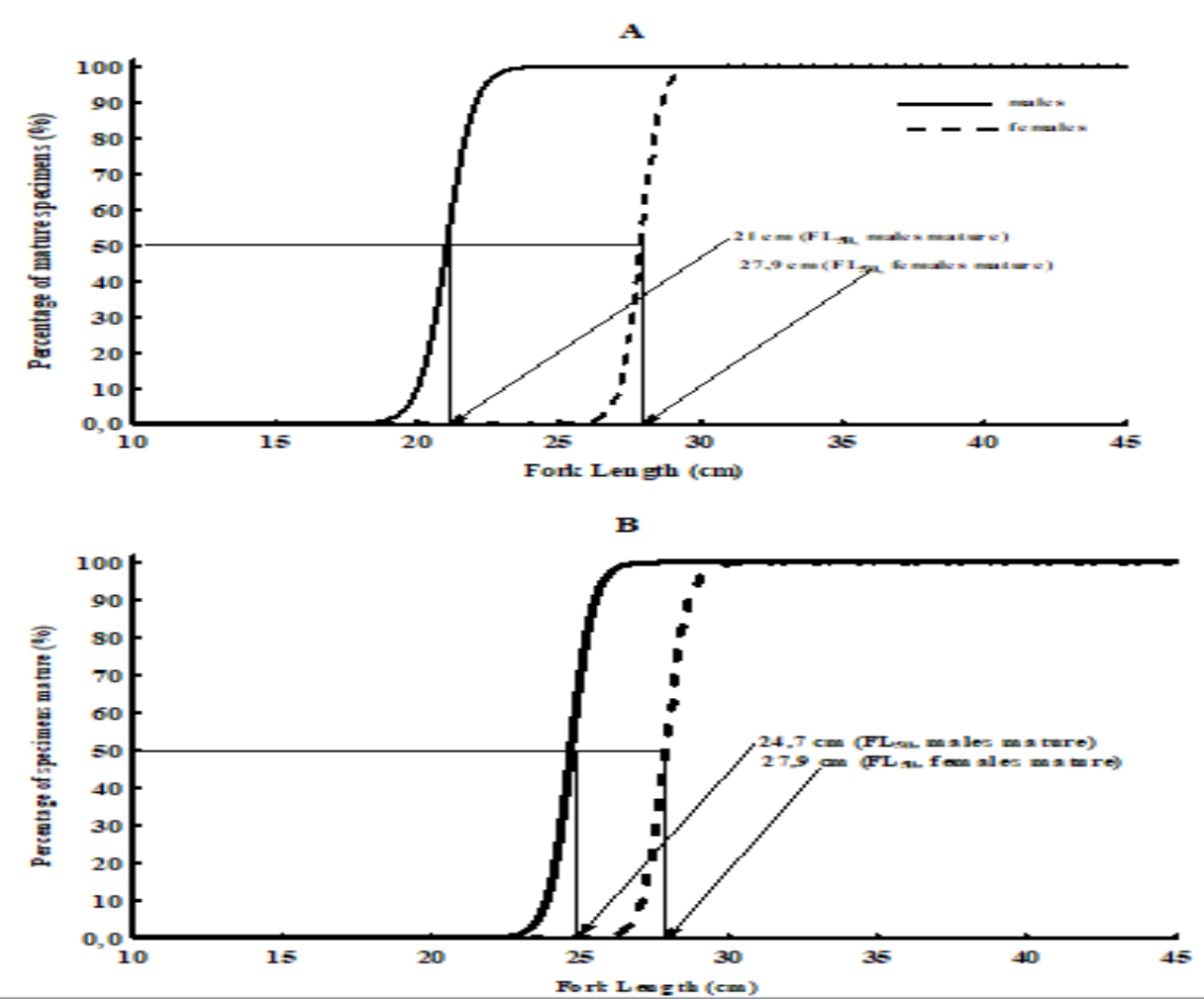

Figure 2: Curve at first sexual maturity (FL50) with fork length in males and females of Liza falcipinnis in Ebrié (A) and Grand-Lahou (B) lagoons

\subsection{Seasonal Evolution In Gonado Somatic (GSI) and Hepato Somatic Indices (HSI) And Factor Condition (K)}

From one year to the next, the monthly variation of (GSI), (HSI) and K in males and females not revealed a significant difference however the lagoons. Consequently, two years data were mixed. In Ebrié lagoon, monthly changes in the GSI for males and for females (Figure 3) revealed a decrease from November to April (February) in both sexes. A further increase was observed, culminating in a peak in October and November in the both sexes. In Grand Lahou lagoon, The GSI variations were the same in except that after the peak in November, GSI declined gradually until April in both sexes. Following the seasonal cycle of the gonado somatic indice (Figure 4); three phases were identified in gonads activities: quiescence; maturation and the reproduction phase. The ovary began to develop between July to September in Ebrié lagoon and between August to October in Grand Lahou lagoon. After a quiescent period of three months (April to June in Ebrié lagoon and May to July in Grand Lahou lagoon). Reproduction phase is extended and last from November to February, peaking in october and November with the highest average values of 0.87 \pm 0.00 for males and $9.29 \pm 0.31$ for females in Ebrié lagoon; then peaking in November with highest average values of $0.89 \pm 0.06$ for males and $5.67 \pm 0.41$ for females in Grand Lahou lagoon. Concerning HSI, mean by month of both sexes followed the same pattern in both lagoons. HSI increased from January through June where a peak was attained a(the means ranged $0.51 \pm 0.05$ to $0.93 \pm 0.07$ and $0.77 \pm 0.04$ to $1.00 \pm 0.01$ respectively for the males and females in Ebrié lagoon and $0.60 \pm 0.02$ to $0.76 \pm 0.03$ for the males and $0.79 \pm 0.01$ to $1.06 \pm 0.02$ for the females in 
Grand-Lahou lagoon). Then, they decreased gradually July to December in both sexes and lagoons. As for condition factor, they were presented the same pattern with GSI in both sexes and lagoons.

\subsection{Monthly Variation of Percentage of Maturity Stage}

The monthly evolution of maturity stages showed that Liza falcipinnis spawned all year. In Ebrié lagoon, the stages 3, 4, 5 and 6 were presented all year for males contrary to the stage 1 where was absent of both sexes. In males, the first stages 5 were appeared in August (Figure 4). In this month, the stages 4 and 5 were represented $88.89 \%$ and peaking in October which decreased gradually until May. It was the same case in females. In this, the first stages 4 and 5 were apparead in September $(22.22 \%)$, this rate creased and peaking in November then decreased until May. In Grand-Lahou lagoon, the stage 2 and 1 for males were absents. The maturity sexual stages were represented by the stages 3, 4 with a high proportion of stage 5 specimens. In this last stage, the important monthly were marked in August, November, February and April for males and November, February and March for females (Figure 4).

\subsection{Spawning Period of Reproduction}

The combination of the monthly change in gonad index (GSI) and the monthly change in the percentage of sexual maturity leads us to say that in the Ebrié lagoon, Liza falcipinnis gonadal maturation begins in September and ends in November. It is followed by the laying December to April and a sexual rest period from May to August. The situation is the same regarding this species in the Grand Lahou lagoon (Figures 3 and 4).

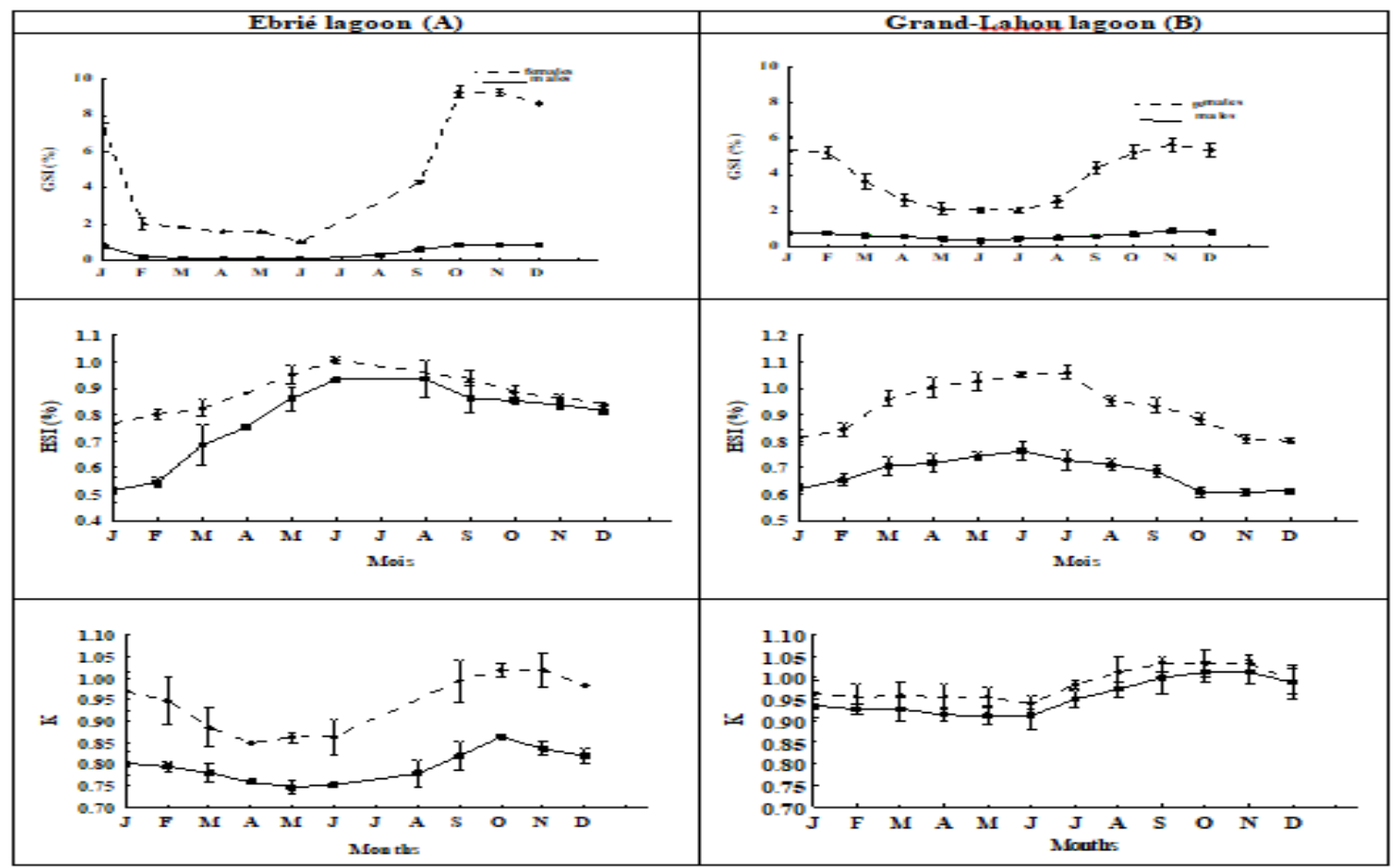

Figure 3: Monthly variations of the gonadosomatic (GSI), hepatosomatic (HSI) indices and condition factor $(\mathrm{K})$ of Liza falcipinnis males and females in Ebrié 5(A) and Grand-lahou lagoons (B) 
Ebrié Lagoon
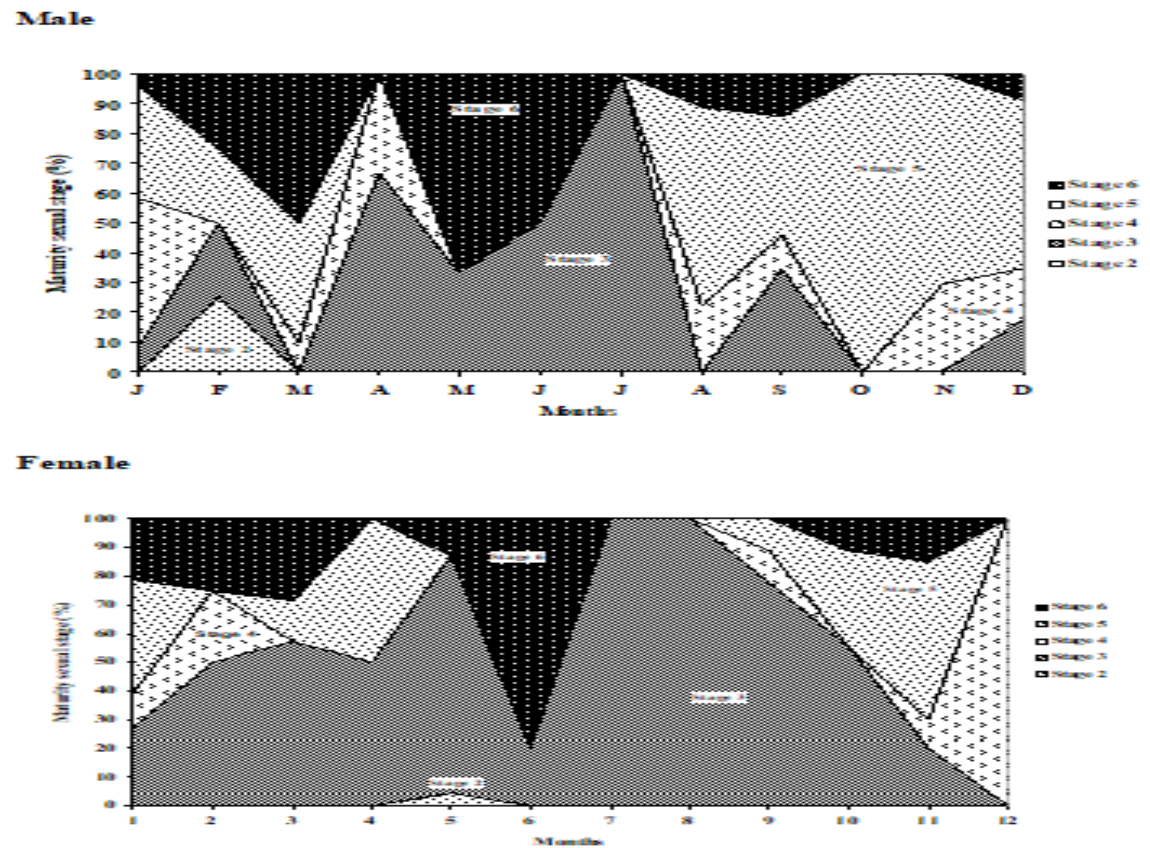

Figure 4: Monthly variation of percentages of sexual maturity in males and females of Liza falcipinnis in Ebrié and Grand Lahou lagoons

Grand-lahou Lagoon

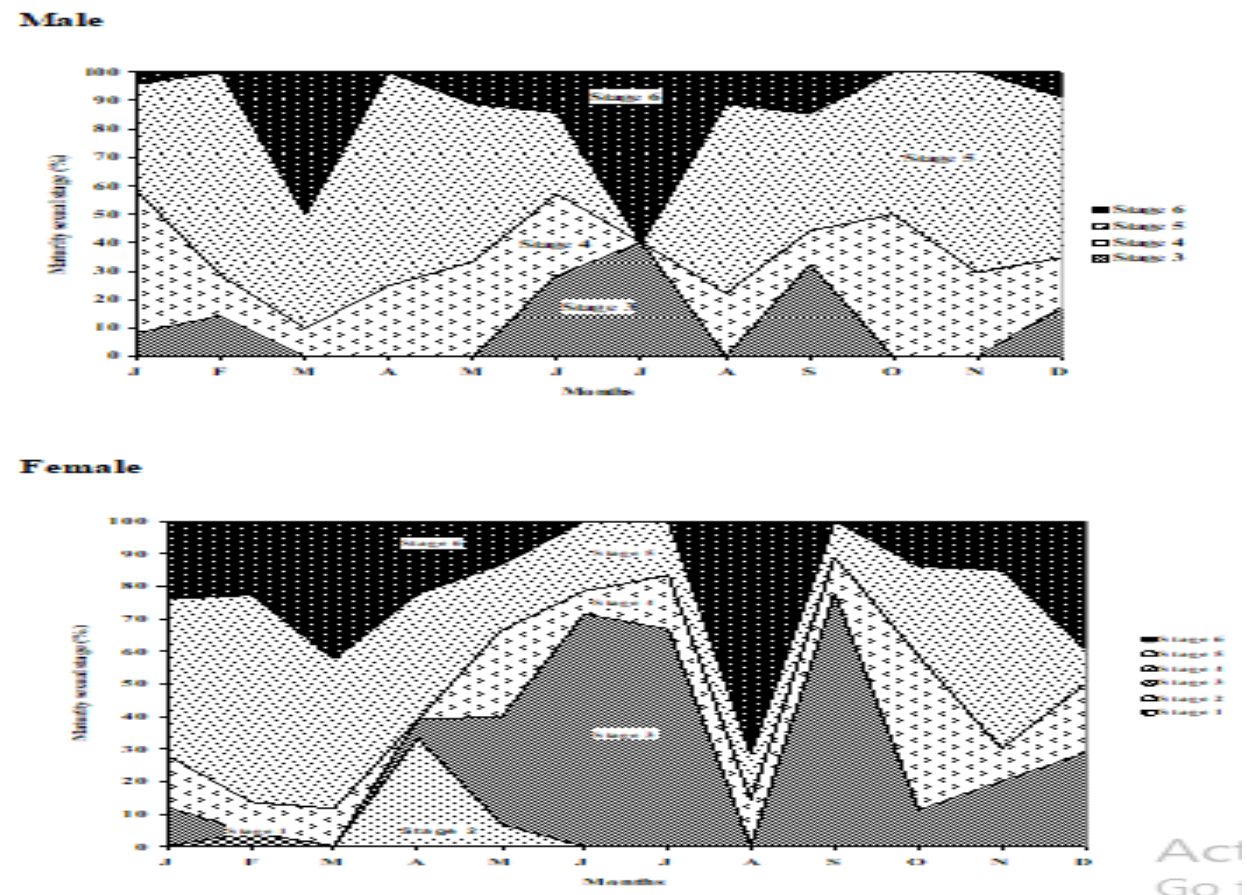

Figure 4 (suite): Monthly variation of percentages of sexual maturity in males and females of Liz falcipinnis in Ebrié and Grand Lahou lagoons 


\subsection{Oocytes Diameter and Fecundity}

Absolute fecundity in Ebrié lagoon varied from 119738 to 833145 oocytes for females of 27.2 and $37.0 \mathrm{~cm}$ (FL) with a total weight from 213 to $528 \mathrm{~g}$. In Grand-Lahou lagoon, the absolute fecundity varied from 101598 to 942348 oocytes for females of 26.9 and $36.2 \mathrm{~cm}$ (FL) and weight total from 22.94 to $541.27 \mathrm{~g}$. Absolute fecundity was positively correlated at size (Figure 5) and weight (Figure 6) of Liza falcipinnis respectively in Ebrié lagoon and Grand-Lahou lagoons. The correlation coefficients are 0.72 and 0.71 and 0.56 and 0.52 respectively in Ebrié and Grand Lahou lagoons for absolute fecundity-length relationships and absolute fecundity-total mass. The values of correlation coefficients indicate a significant liaison between the two relationships. In this specie, the oocytes diameters were studied in stage 4, 5 and 6 in the both lagoons. Stage 4 of sexual maturation, oocytes diameters were varied from 0.3 to 1.2 with a large majority of diameters between 0.50 and $0.60 \mathrm{~mm}$. Stage 5 is dominated by oocytes diameters ranging from 0.70 to 0.80 $\mathrm{mm}$. About the stage 6 , it is dominated with oocytes diameters between 0.35 and $0.40 \mathrm{~mm}$. The oocyte diameter frequency distribution was suggested synchronous oocyte development with a single spawning. The oocyte diameter was varied from 0.70 to $0.80 \mathrm{~mm}$ for females at stage 5 in both lagoons (Figure 6).

\section{Ebrié lagoon (A)}
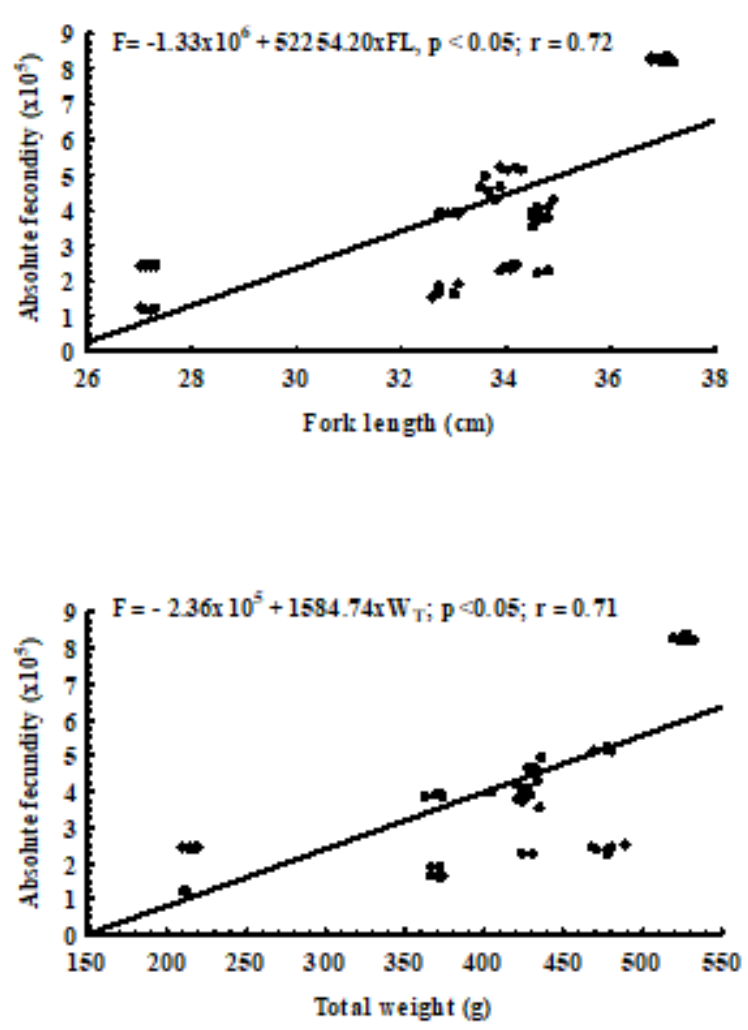

Grand-Lahou lagoon (B)
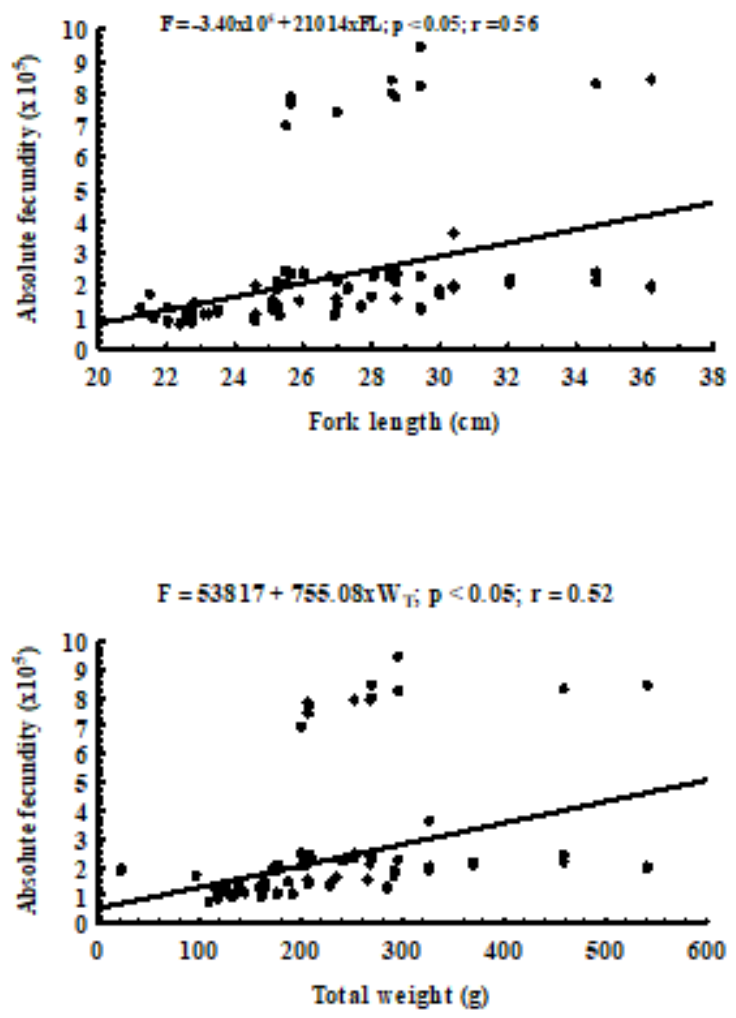

Figure 5: Relationship of absolute fecundity between fork length and Relationship of absolute fecundity between total weight in Liza falcipinnis in Ebrié (A) and Grand-Lahou (B) lagoons 

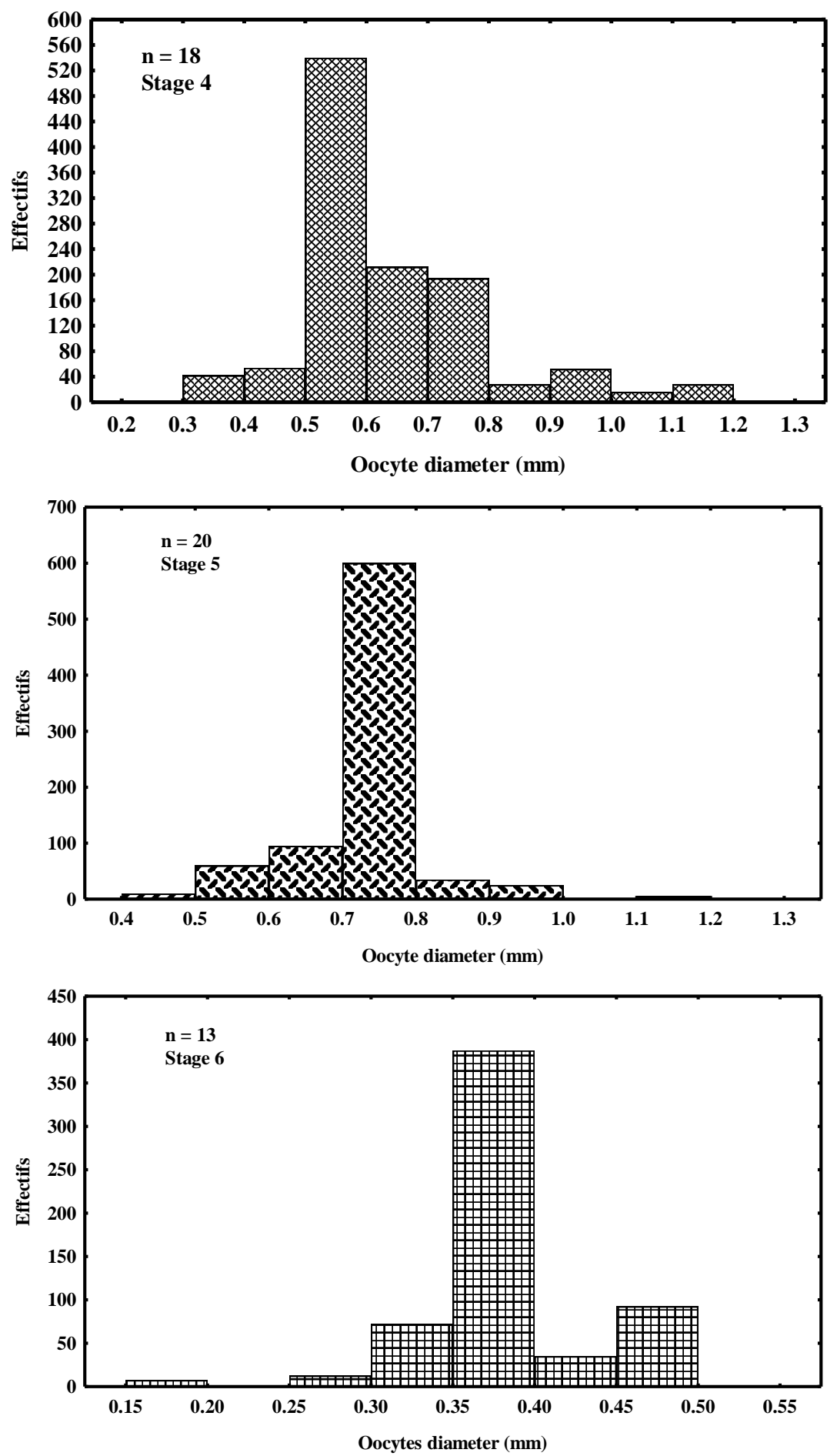

Figure 6: Frequencies distributions of oocytes diameters of Liza falcipinnis females

\section{Discussion}

A sex ratio unbalanced in the mullets was observed by several authors as Albaret and Legendre (1985) and Abou-Seedo and Dadzie (2004). According to Sylla et al., (2009) and Abou-Seedo and Dadzie (2004) which are worked on Carangidae and Cichlidae, the prevalence of one of the sexes 
is a relatively frequent phenomenon at many fish teleostens species and could come from a differential growth according to sex (Chikou et al., 2007). These could explain the ascendancy of females observed to this specie in each lagoon. Some authors showed a predominance of the females (Ergene, 1998; Ameur et al., 2003; Abou-Seedo and Dadzie, 2004; Mohamed, 2004; Ilkyaz et al., 2006; Patimar, 2008) as it is the case of this study. On the other hand, others authors showed a predominance of the males (Albaret and Legendre, 1985; Bedoui, 2002; Katselis et al., 2002; Matthieu and Mohamed, 2002). To explain the sex ratio unbalance, several assumptions were proposed by Atse et al., (2008); Ameur et al., (2003) and Albaret and Legendre (1985) to account for the total sex-ratio and the relationship between the sex-ratio and size in favour of the females observed at Liza falcipinnis in the two lagoons. This could be due to the differential growth in favour of the females previously evoked; higher mortality of the males at the larval and youthful stages; less accessibility of the males due to ethologic differences related to the sex; bordering distribution of the males in lagoon at certain periods of their cycles biological or by possible migration towards the sea; displacement for the research of food. From the present study, it is also evident that females Liza falcipinnis reach sexual maturity at a larger size than the males as it is the general case at Mugilidae (Ameur et al., 2003; Abou-Seedo and Dadzie, 2004; Ibañez Aguirre et al., 2004). Similar results were reported on the same species from Arabian gulf (Abou-Seedo and Dadzie, 2004), from Pakistan (Hoda and Qureshi, 1989) and from Ivory Coast (Albaret and Legendre, 1985). This could ensure that the fish have more accommodative capacity for increased egg production as suggested by Owiti and Dadzie (1989). This discrimination could be related to a difference on the level of the differential growth rate between the males and the females (AbouSeedo and Dadzie, 2004).

The analyses of the GSI and the percentage of gonadal maturation stages in the both lagoons shows that gonadal maturation begins in September (dry season) for are completed in November (rain season). It is followed by the laying December (beginning dry season) to April (beginning rain season) and a sexual rest period from May (rain season) to August (beginning dry season). The spawning period coincides with the flood season of the lagoon september to December. This creates ideal conditions for the survival of larva and fingerlings because food is abundant. Indeed, during the flood season, nutrients are drained by the rich runoff in organic matter. The decomposition of the organic matter enriches the environment in mineral salts, which would lead to the proliferation of algae (Komoé, 2010). The availability of food during this period is utilized so that the larva and fingerlings do not have to provide any effort to travel long distances to feed (Offem et al., 2007). This reproductive strategy of LF could be explained by the fact that, abiotic and climate variables constituting the ecological characteristics of a middle, each specie respond to environmental factors as its ecological needs, its reproductive strategy and within it for different tactics it is likely to develop (Benech and Quensière, 1985). The presence of individual at stage 5 of sexual maturation in both lagoons makes it possible to suggest that the reproduction of Liza falcipinnis takes place in the both lagoons. Our results are similar to several authors work on Liza falcipinnis as Albaret (1984, 1987); Albaret and Legendre (1985). It is the case also of Liza ramata who reproduces in Akgöl-Paradeniz lagoon in Turkey (Ergene, 1998). However Albaret and Legendre (1985), Albaret $(1984 ; 1987)$ did not exclude the possibility of reproduction in sea for this specie. During the spawning period, the HSI decreases while the GSI increases; on the other hand, the GSI and K evolve in a similar way. This suggests that Liza falcipinnis would draw his reserves necessary to the maturation of the gonads in the liver. In the same way, the spawning period corresponds to the period when the condition factor $(\mathrm{K})$ is lowest. This would convey a 
slimming of fish and would indicate that this last would use also its energy reserves contained in the muscles and the viscera to ensure the reproduction (Behoui et al., 2002). Similar observations were made at Liza aurata (Behoui et al., 2002) of the Tunisian coasts.

The absolute fecundity increases with size of females (Patimar, 2008; Abou-Seedo and Dadzie, 2004). In general, absolute fecundity was very high in Mugilidae (Matthieu and Mohamed, 2002; Donough et al., 2003). Patimar (2008) indicates for Liza ramata that absolute fecundity values ranged from 126668 to 439265 oocytes for females measuring for fork length (FL) ranging between $26.9 \mathrm{~cm}$ and $34.5 \mathrm{~cm}$. As Abou-Seedo and Dadzie (2004) were observed for Liza Klunzingeri a fecundity which varying from 88.896 to 185.929 oocytes for females with standard length (SL) ranging between 15.0 and $17.5 \mathrm{~cm}$. This high fecundity would be a strategy to maximize the survival of the progeny of the species which do not practise parental protection as it is the case at Liza falcipinnis (Mellinger, 2002; Sylla et al., 2009). The predominance of mature oocytes of successive sizes in the ovaries of Liza falcipinnis during the spawning period, coupled with the unimodal pattern of oocyte diameter frequency distribution suggest that the specie has a synchronous oocyte development with a single spawning (Abou-Seedo and Dadzie, 2004).

\section{Conclusion}

The study made it possible to show that the sex-ratio of Liza falcipinnis is in favour of the females whatever the lagoon and males reach sexual maturity faster than females. Liza falcipinnis spawned in lagoon from December to April in the both lagoons. The unimodal pattern of oocyte diameter frequency distribution suggests a synchronous development of the oocytes with a single spawning. The high fecundity of this specie 119738 to 833145 oocytes in Ebrié lagoon for females from sizes ranging between 27.2 and $37.0 \mathrm{~cm}$ (FL) and 101598 to 942348 oocytes for females of sizes varying between 26.9 and $36.2 \mathrm{~cm}$ (FL) Grand-Lahou lagoon could be an advantage for fish culture.

\section{References}

[1] Abou-seedo, F. \& Dadzie, S. (2004). Reproductive cycle in the male and female grey mullet, Liza klunzingeri in the Kuwaiti waters of the Arabian gulf. Cybium, 28 (2): 97-104.

[2] Albaret, J.J. (1984). Premières observations sur la faune ichtyologique de la Casamance. Centre de Recherches Océanographiques de Dakar-Thiaroye. Archive n¹31, 22 p.

[3] Albaret, J.J. (1987). Les peuplements de poissons de la Casamance (Sénégal) en période de sécheresse. Revue. Hydrobiologie Tropicale. 20 (3-4) : 291-310.

[4] Albaret, J.J. (1992). Mugilidae. In : Lévêque C, Paugy D. \& Teugels GG, Faune des poissons d'eaux douces et saumâtres d'Afrique de l'Ouest. Tome II. ORSTOM, France, 780 - 788.

[5] Albaret, J.J. \& Legendre, M. (1985). Biologie et écologie des Mugilidae en Lagune Ebrié Côte d'Ivoire, Intérêt potentiel pour l'aquaculture lagunaire. Revue Hydrobiologie tropicale 18 (4): 281 $-303$.

[6] Ameur, B., Bayed, A. \& Benazzou, T. (2003). Rôle de la communication de la lagune de Merja Zerba (Gharb, Maroc) avec l'océan Atlantique dans la reproduction d'une population de Mugil cephalus L. (Poisson Mugilidae). Bulletin Institut Scientifique, Rabat, section Sciences de la Vie. $\mathrm{n}^{\circ} 25,77-82$.

[7] Atsé B.C., Konan K.J., \& Kouassi N.J. (2008). Biologie de la reproduction du Cichlidae Tylochromis jentenki dans la lagune Ebrié (Côte d'Ivoire). Cybium, 33 (1): 11-19. 
[8] Bedoui R.F., Gharbi H., \& Abed A.E. (2002). Période de reproduction et maturité sexuelle de Liza aurata (Poisson, Mugilidae) des côtes Est et Sud tunisiennes. Bulletin de 1'Institut National des Sciences et Technique de la Mer, Salammbô, 29.

[9] Benech V., \& Quensière J. (1985). Stratégie de reproduction des poisons du Tchad en période de "Tchad Normal" (1966-1971). Revue d'Hydrobiologie Tropicale, 18 (3): 227-244.

[10] Chikou A., Laley P., Philipart J.C., \& Vandewalle P. (2007). Quelques aspects de la biologie de reproduction chez Clarias ebriensis (siluriformes, Clariidae) dans le delta de l'Ouémé au Bénin (Afrique de l'Ouest). Cybium, 31 (2) : 207-215.

[11] Durand J.R., \& Guiral D. (1994). Hydroclimat et hydrochimie. In : Durand JR, Dufour P, Guiral D, Zabi SG (eds), Environnement et ressources aquatiques de Côte d'Ivoire. Les milieux lagunaires. Tome II. ORSTOM, Paris. 129 - 136.

[12] Ergene S. (1998). Reproduction caracteristics of thinlip grey mullet, Liza ramada (Risso, 1826) inhabiting Akgöl-Paradeniz lagoons (Göksü delta). Turkish Journal of Zoology, 24: 159-164.

[13] Ghorbel M., Jarboui O., Bradai M.N., \& Bouain A. (1996). Détermination de la taille de première maturité sexuelle par une fonction logistique chez Limanda limanda, Pagellus erythrinus et Scorpaena porcus. Bulletin de l'Institut National des Sciences et Technologie de la Mer, $\mathrm{n}^{\circ}$.spécial. 1996; 3: $24-27$.

[14] Hoda S.M.S., \& Qureshi N. (1989). Maturity, sex ratio and ovary diameter and fecundity of the mullet Liza klunzingeri (Day) from Karachi-Sind waters. Indian Journal of Fisheries, 36: 183-192

[15] Ibanez Aguirre, A.L., \& Gallardo-Cabello, M. (2004). Reproduction of Mugil cephalus and M.curema (Pisces: Mugilidae) from a coastal lagoon in the gulf of Mexico. Bulletin of Marina Science, 75 (1): $37-49$.

[16] Doi: https://doi.org/10.5343/bms.2014.1004

[17] Ilkyak, A.T., Firat, K., Saka, S., \& Kinacigil, H.T. (2006). Age, growth, and sex ratio of golden Grey mullet, Liza aurata (Risso, 1810) in homa lagoon (Izmir bay, aegean sea).

[18] Turkish Journal of Zoology, 30: 279-284.

[19] Katselis, G., Koutsikopoulos, C., \& Kaspiris P. (2002). Age determination and growth of leaping mullet, (Liza saliens, R. 1810) from the Messolonghi Etoliko lagoon (western Greece). Mediterranean Marine Science, 3/2: 147-158.

[20] DOI: http://dx.doi.org/10.12681/mms.253

[21] Komoé, K. (2010). Distribution du phytoplancton dans le complexe lagunaire de Grand-Lahou (Côte d'Ivoire). Thèse de Doctorat. Université Abidjan Cocody. 341 p.

[22] Konan K.S., Kouassi, A.M., Adingra, A.A., Dongui, B.K., \& Gnakri, D. (2008). Variations saisonnières des paramètres abiotiques des eaux d'une lagune tropicale: La lagune de Grand-Lahou, Côte d'Ivoire. European Journal of Scientific Research, 21 (3) : 376-393.

[23] Matthieu, B., \& Mohamed, O.V.M. (2002). Le Mulet en Mauritanie: biologie, écologie, pêche et aménagement. PRCM. 53 p.

[24] Donough, Mc. C.J., Roumillat, W.A. Wenner, C.A. (2003). Fecundity and spawning season of striped mullet (Mugil cephalus 1.) in south Carolina estuaries. Fisheries bulletin, 101: 822-834.

[25] Mellinger, J. (2002). Sexualité et reproduction des poissons. CNRS EDITIONS, Paris. 349 p.

[26] Mohamed, O.M.V. (2004). Etude de la dynamique des systèmes d'exploitation et de l'éco-biologie de la reproduction de trois Mugilidés : Mugil cephalus (Linnaeus, 1758). Lizaaurata (Perguria, 1892) et Mugil capurrii (Risso, 1810). Analyse de leurs Stratégies d'Occupations des secteurs littoraux Mauritaniens et de leurs possibilités d'Aménagement. Thèse de Doctorat. Université de Nice-Sophia Antipolis. France, 129 p.

[27] Ntakimazi, G., Nzigidahera, B., Nicayenzi, F., \& West, K. (2000). Etude spéciale de biodiversité (ESBIO) Rapport. L'état de la diversité biologique dans les milieux aquatiques et terrestres du delta de la Rusizi. 70 p.

[28] Offem, B.O., Adegbejo-Samsons, Y., \& Omoniyi, I.J. (2007). Biological assessment of Oreochromis niloticus (Pisces: Cichlida, Linne, 1958) in a tropical flood plain river. African Journal of Biotechnology, 6 (16): 1966-1971. 
[29] Owiti, D.O., \& Dadzie, S. 1989. Maturity, fecundity and the effect of reduced rainfall on the spawning rythm of a siluroid catfish, Clarias mossambicus (Peters). Aquaculture and Fishiseries Management, 20: 355-368.

[30] DOI: $10.1111 / \mathrm{j} .1365-2109.1989 . t b 00363 . x$

[31] Patimar, R. (2008). Some biological aspects of the sharpnose mullet Liza saliens (Risso, 1810) in Gorgan bay-Miankaleh wildlife refuge (the southeast Caspian sea).

[32] Turkish Journal of Fisheries Aquatic Sciences, 8: 225-232.

[33] Robert, B.I, \& Jessa, H.O. (2003). Studies on aspects of the biology of Tilapia mariae (Boulenger,1899) (Osteichthyes Cichlidae) in Ethiope River, Niger Delta, Nigeria. African Zoology, 38 (2): 255 - 264.

[34] DOI: $10.1080 / 15627020.2003 .11407279$

[35] Sahar, F.M. (2004). Population dynamics of keeled mullet, Liza carinata and golden grey mullet, Liza aurata at the bitter lakes. Egyptian Journal of Aquatic Research, 30 (B): 315 - 321.

[36] Sylla, S., Atse, B.C., \& Kouassi, N.G.J. (2009). stratégie de reproduction du Carangidae Trachinotus teraia cuvier, 1832 dans la lagune Ebrié (Côte d'Ivoire). Science Nature, $6: 83-94$.

[37] DOI :10.4314/scinat.v6i1.48662

[38] Wright, J.M. (1988). Seasonal patterns and tropic relation ships of fish assemblage of the nonestuarine Sulaibikhat Bay, Kuwait. Marine. Biology, 100: 13 - 20.

*Corresponding author.

E-mail address: djadji.gervais2@gmail.com 